\title{
THE EFFECT OF A MOTOR VEHICLE REGISTRATION STATUTE ON RESULTING TRUSTS IN AUTOMOBILES*
}

A RESULTING trust is an implied trust based on the intentions of parties to a transfer of property. Their intentions may be presumed from the nature of the transaction. ${ }^{1}$ Thus when $A$ pays the consideration for a transfer of property from $B$ to $C$, the law presumes that $A$ and $C$ intend to create a trust with $C$ as trustee for $A$ 's benefit. ${ }^{2} C$ is considered to have taken a bare legal title to the property; the beneficial or equitable interest in the property is in $A$. Although the doctrine was developed with regard to land, ${ }^{3}$ it also applies to personal property, ${ }^{4}$ in which case the presumption that the parties intended to create a trust rather than to execute a gift appears to be stronger. ${ }^{5}$ However, the ownership of an important item of personal property, motor vehicles, is regulated by statutes which require registration of title. Since ownership is declared to be in the holder of the certificate of title, such statutes may be construed to abolish the resulting trust doctrine which recognizes that ownership may be in someone other than the legal titleholder. ${ }^{6}$

*In re Estate of Case, 161 Ohio St. 288, 118 N.E.2d 836 (1954).

1. McGovern v. Knox, 21 Ohio St. 547 (1871); 3 Scort, Trusts $\$ 440$ (1939); Gilmer, Current Developments in Resulting Trusts and Constructive Trusts in Kentucky, $42 \mathrm{Ky}$. L.J. 455 (1954). Three types of resulting trusts are generally recognized: those resulting from the failure of an express trust; those resulting from the exhaustion of an express trust; and those resulting from purchase transactions in which one person pays the consideration and another takes title. The third type is known as a purchase money resulting trust.

Where the trust relationship is created by an express agreement, either written or oral, an express trust arises. 1 Scort, Trusts $\S \S 2.1,17.1,23$ (1939). Express trusts in land must be in writing in order to satisfy the Statute of Frauds. Ibid. But resulting trusts in land need not satisfy the Statute of Fratds. 3 Scorr, Trusrs $\S 440$ (1939).

2. Cropper v. Lambertson, $174 \mathrm{Md}$. 24, 197 Atl. 576 (1938); Chichester v. Chichester, 209 Miss. 628, 48 So. 2d 123 (1950); 3 Scort, Trusts $\$ 440$ (1939). When property is purchased in the name of certain relatives who would normally be the object of the purchaser's bounty, the transaction results in a presumption of gift. Link v. Emrich, 346 I11. 238, 178 N.E. 480 (1931); 3 Scotr, Trusts $\$ 442$ (1939).

3. 3 SCotT, TRUSTs $\$ 404$ (1939).

4. Bullman v. Edney, 232 N.C. 465,61 S.E.2d 338 (1950) (automobile); Norman v. Burks, 93 Cal. App. 2d 687, 209 P.2d 815 (1949) (realty, home furnishings, ring, and other personalty); Reynolds v. Kenney, 87 N.H. 313, 179 Atl. 16 (1935) (bonds); 2A Bogert, Trusts aNd Trustees $\S 454$ n.34 (1953); 3 Scott, Trusts $\$ 440$ (1930).

5. "A different rule [from that of land], however, prevails as to a trust in personal property, and the owner thereof can impress it with a trust by means and acts that would be wholly insufficient to impress a trust upon the title to land." Richards v. Parsons, 7 Ohio App. 422, 426 (1916).

6. Motor vehicle registration statutes may be compared to the Statute of Frauds to the extent that they require a written instrument, the registration certificate, to evidence ownership of the motor vehicle. It is well recognized that the Statute of Frauds does not affect resulting trusts. See note 1 supra. Similarly, several courts have already concluded that motor vehicle registration statutes do not abolish resulting trusts in motor 
In the recent case of In re Estate of $\mathrm{Casc}^{7}$ an administrator sought to have a resulting trust declared in two Cadillacs. Decedent had purchased and paid for both automobiles. ${ }^{8}$ He retained possession of the velicles, exercised complete dominion over them, and paid all the expenses incurred in their operation and maintenance. ${ }^{9}$ But he had their titles placed in his daughter's name. The Probate Court declared a resulting trust, ${ }^{10}$ but was overruled by an appellate court which held that the automobiles had been a gift to the daughter. ${ }^{11}$ The Ohio Supreme Court, disregarding the gift rationale, ${ }^{12}$ affirmed on the basis of its interpretation of the Ohio Certificate of Motor Vehicle Title Law. ${ }^{13}$ The

vehicles. Henry v. General Forming, Itd., 33 Cal. 2d 223, 200 P.2d 785 (194\$); Dea v. Sutter, 222 S.W.2d 541, 543 (Mo. App. 1949) (dictum); Miajors v. MLajors, 349 Pa. 334, 338, 37 A.2d 528, 529 (1944) (same). See also note 30 infra. Although the Ohio statute is more rigid than some of the statutes involved in these cases, the Ohio court was not compelled to construe it so as to abolish completely resulting trusts in motor vehicles. See pp. 460-63 infra.

7. 161 Ohio St. 288, 118 N.E.2d $\$ 36$ (1954).

8. One of the vehicles was paid for with decedent's funds, and the other was partly financed by a loan secured by a note. Decedent and his daughter both signed the note as co-makers, but decedent paid the debt with his own funds. Transcript of Rccurd, pp. 6-10, In re Case's Estate, 161 Ohio St. 2S8, 118 N.E.2d 836 (1954).

9. There were two short periods of time during which the daughter used each vehicle with decedent's permission. Id. at 6-11.

10. In re Estate of Case, No. 148,451, P. Ct., Franklin County, Ohio, Oct. 13, 1952.

11. In re Estate of Case, 121 N.E.2d 679 (Ohio App. 1953). Since the transier of the property in this case was to the daughter of the purchaser, there is a presumgtion of gift. See note 2 supra. The appellate court held that the presumption of gift was not rebutted by the administrator and that therefore no resulting trust would te declarod. Id. at 683 .

12. Apparently the court felt that, if no statute were involvid, the evidence would not require that the daughter be given the vehicles. See note 26 infro. But if the $c$ urt fult that the equities of the situation required that the daughter have the vehicles, it cauld have reached that result by using the presumption of gift. See note 11 supra. However, the court based its decision entirely on its interpretation of the statute and refused to consider the gift possibility.

13. OHIO REv. CODE C. 4505, $\$ 4505.04$ (1951).

"Certificate of title as evidence of ownership.

"No person acquiring a motor vehcile from the owner thereof, whether such owner be a manufacturer, importer, dealer, or otherwise, hereafter shall acquire any right, title, claim, or interest in or to said motor vehicle until he shall have had issued to him 3 certificate of title to said motor vehicle, or delivered to him a manuiacturer's or importer's certificate for the same; nor shall any waiver or estoppel operate in favor of such person against a person having possession of such certificate of title, or manufacturer's or importer's certificate for said motor vehicle for a valuable consideration. No court in any case at law or in equity shail recognize the right, title, claim, or interest of any persen in or to any motor vehicle, hereafter sold or disposed of, or mortgaged or encumbared, unless evidenced by a certificate of title or manufacturer's or importer's certificate duly issued, in accordance with the provisions of this chapter." The section was amended in 1953 to permit ownership to be evidenced by stipulations of the partics or admission in the pleadings as well as by a duly issued certificate of title.

Ohio has one of the most rigid and elaborate statutes, on its face, in this field. For an example of the rigidity with which the statute has been applied, see Kelley Kar Co. v. 
court held that since the wording of the statute clearly prohibited all courts from recognizing any interest in a motor vehicle other than that evidenced by the certificate of title, the statute must be construed as having completely abrogated the resulting trust doctrine as to such vehicles.14

The court recognized, however, that the statute does not preclude a finding of ownership in someone other than the holder of the certificate of title where fraud or theft is involved. ${ }^{15}$ In the case of theft the exception is apparently based on a section of the statute which provides for the cancellation of certificates to stolen vehicles. ${ }^{16}$ But in the case of fraud there is no statutory authorization for an exception to the rigid wording of the motor vehicle registration statute. ${ }^{17}$ Yet In re Estate of Case approved those decisions which, when fraud was involved, held the certificate of title void ab initio and recognized interests in motor vehicles not evidenced by a certificate. ${ }^{18}$ Thus even this court is apparently unwilling to be bound by a strictly literal interpretation of the statute where the equities of a situation require a contrary result. ${ }^{10}$

Finkler, 155 Ohio St. 541, 99 N.E.2d 665 (1951). See aiso Comment, 37 Mrcr. L. Rev. 758 (1939).

14. In re Estate of Case, 161 Ohio St. 288, 293, 118 N.E.2d 836, 839 (1954).

Section 4505.04 is really not as clear as the court decides. It specifically provides that "no person acquiring a motor vehicle ... shall [have] any waiver or estoppel operate in [his] favor ... against a person having possession of such certificate of title . . . for said motor vehicle for a valuable consideration." This implies that even under this statute waiver or estoppel can operate in favor of one in possession of a motor vehicle against the holder of the certificate of title if the titleholder had not given consideration for the certificate. Yet, if a court allowed waiver or estoppel to operate against the holder of the certificate, it would be recognizing an interest in the motor vehicle not evidenced by a certificate of title. This is precisely what the Ohio court concluded the statute did not allow.

15. "It is to be noted that neither fraud nor theft is involved in the instant case. This decision will not control in a situation where the facts may warrant a decision that a certificate of title under the Ohio act is voidable on account of fraud." In re Estate of Case, 161 Ohio St. 288, 293, 118 N.E.2d 836, 839 (1954).

16. Onto Rev. Cone $\S 4505.17$ (1953). See discussion of this section in Mock v. Kaffits, 75 Ohio App. 305, 62 N.E.2d 172 (1944).

17. The only sections of the Certificate of Motor Vehicle Title Law which refer to fraud are OHIo Rev. CODE $\S \S 4505.19,4505.99$ (1953). These sections are penal in nature and make no provision for what shall be done when a certificate of title is issued on the basis of a fraudulent application. If the reasoning of the instant case interpreting Onio REv. CODE \& 4505.04 (1953) were to apply with regard to such a certificate of title, a court would have no alternative but to recognize title in a motor vehicle based on a fraudulently procured certificate.

18. Associates Discount Corp. v. Colonial Finance Co., 88 Ohio App. 205, 98 N.E.2d 848 (1950); Mock v. Kaffits, 75 Ohio App. 305, 62 N.E.2d 172 (1944); Automobile Finance Co. v. Mundy, 137 Ohio St. 504, 30 N.E.2d 1002 (1940).

19. Compare Automobile Finance Co. v. Mundy, 137 Ohio St. 504, 30 N.E.2d 1002 (1940) (plaintiff not permitted to rely on a fraudulently procured certificate to establish ownership in a replevin action), with Kelley Kar Co. v. Finkler, 155 Ohio St. 541, 99 N.E.2d 665 (1951) (bona fide purchaser possessing certificate of title based on a previous fraudulently procured certificate permitted to retain possession). See 13 OHio ST. L.J. 296 (1952). 
If courts are competent to declare an exception for fraud to a statute which on its face provides no such exception, there is no reason why they should not also recognize resulting trusts under the same statute. Many legitimate reasons exist for having title to property in one person's name when the consideration is paid by another $;^{20}$ and the resulting trust doctrine was developed by courts of equity to give effect to the intention of the parties under such circumstances. ${ }^{21}$ On the other hand, equity will not enforce resulting trusts for the benefit of payors when the transaction has been tainted with fraud or illegality. ${ }^{22}$ Therefore, to refuse to recognize resulting trusts in automobiles because of the registration statute is to deprive innocent purchasers of such property for the benefit of unconscionable transferees. ${ }^{23}$

Refusing the payor the right of equitable ownership would also unjustly injure third parties who have interests in the payor's property. Creditors have rights to property equitably owned by their debtor, ${ }^{24}$ and heirs have rights

20. The following includes the more important reasons: to provide seeurity for a debt owed by the purchaser to the transferee; to permit an agent to purchase property in his own name for the benefit of his principal; to facilitate a conditional sale by leaving legal title in the vendor; to facilitate a loan arrangement by putting title in the lender's name; to facilitate resale as where several persons contribute to the payment of the purchase price or where the purchaser is married and lives in a state which recognizes dower rights; and to provide convenience to the purchaser in the actual transfer of title 3 Scorr, TRUSTS $\$ 440$ (1939).

The argument is sometimes made that only improper motives lead to a purchase in this manner and that resulting trusts should therefore be abolished to prevent wrongdoers from benefiting from their wrongdoing. In fact, however, recognition of resulting trusts often prevents the accomplishment of fraudulent objectives by recognizing in the wrongdoer the very property interest which he seeks to have fuund in somcone else. Thus, if decedent's purpose in the instant case were to give the vehicles to his daughter on his death without payment of any estate tax thereon, judicial recognition of the resulting trust would defeat his attempt to evade the tax. And in situations in which a resulting trust is declared in favor of creditors, injury to the creditors is prevented. See discussion in Dorrington v. Jacobs, 213 Wis. 521, 252 N.W. 307 (1934).

21. 2A Bogert, Trusts and Trustees $\$ 454$ (1953); 3 SCort, Trusts $\$ 404$ (1939).

22. Genth v. Gardner, 85 Colo. 52, 273 Pac. 644 (1928); Watson v. Poore, 18 Cal. 2d 302, 311, 115 P.2d 478, 483 (1941) (dictum); Makinen v. George, 19 Wash. 2d 340, 352-53, 142 P.2d 910, 916-17 (1943) (same); 2A Bogert, Trusts asid Trustees $\$ 463$ (1953) ; 3 Scotr, Trusts $\$ 444$ (1939).

23. Dean Ames, a noted critic of the doctrine of resulting trusts, commented as follows on those cases which rejected resulting trusts on the basis of statutes which specifically abolished them: "It is a step forward, even if a short step, to abolish the artificial presumption of a resulting trust because of the mere payment of the purchase money, for such a presumption favors the buyer unduly. But it is a long step backward to diclare that the statute penalizes the innocent buyer to the aggrandizement of the unconscionable grantee." "[Such statutes are] shockingly unjust in enriching the faithless grantee at the expense of the trusting buyer; ...." Asres, Construclize Trusts Based ufon the Breach of aiz Express Oral Trust of Land in Lectures on Legas. Histu3y 425, 433 (1913).

24. Sayers v. Flack, 190 N.W. 965 (Iowa 1922); Lyons v. Urgalones, 189 Mass. 424, 75 N.E. 950 (1905); Currie v. Look, 14 N.D. 4S, 106 N.W. 131 (1906); 2A Bocess, Trusts and Trustees $\S 454$ (1953); 3 Scotr, Trusts $\S 407$ (1939). 
to property equitably owned by their intestate. ${ }^{25}$ Such third parties have no control over the actual placing of the title in someone else's name, but they would be deprived of their interests if resulting trusts in automobiles were abolished. In the instant case, for example, decedent's heirs may have been denied property which, except for the motor vehicle registration statute, might have been awarded to them. ${ }^{26}$

Moreover, the court could have recognized a resulting trust under that section of the Ohio motor vehicle statute which provides for the issuance of certificates of title upon proof "of the transfer of ownership . . . by operation of law" or by "[certain contractual arrangements] or other similar agreement." "27 This section clearly recognizes that courts can enforce interests in automobiles other than those interests which are evidenced by a registration certificate. ${ }^{28}$ And since a resulting trust is an implied trust based on the intentions of the

25. Montgomery v. McNutt, 214 Ala. 692, 108 So. 752 (1926); Exchange Trust Co. v. Godfrey, 128 Okla. 108, 261 Pac. 197 (1927); Lew You King v. Lew Kay, 174 Wash. 83, 24 P.2d 596 (1933); 2A Bogert, Trusts and Trustees $\$ 454$ (1953); 3 Scotr, TRUSTS $§ 407$ (1939).

26. "Except for the effect of the statute we could agree that the evidence warrants the conclusion that the decedent transferrcd the automobiles or caused them to be trans:ferred to the daughter under circumstances raising an inference that he intended to have transferred to her a bare legal title and not to give her the beneficial interest. Such would be a typical case of resulting trust." In re Estate of Case, 161 Ohio St. 288, 292, 118 N.E.2d 836, 838 (1954). Contra, In re Estate of Case, 121 N.E.2d 679, 683 (Ohio App. 1953).

27. OHIo Rev. CoDE $\S 4505.10$ (1953):

"Certificate of title when ownership changed by operation of law.

"In the event of the transfer of ozenership of a motor velicle by operation of law", as upon inheritance, devise or bequest, order in bankruptcy, insolvency, replevin, or exec11tion sale, or whenever the engine of a motor vehicle is replaced by another engine, or whenever a motor vehicle is sold to satisfy storage or repair charges, or reposscssion is had upon default in performance of the terms of a chattel mortgage, trust reccipt, conditional sales contract, or other similar agreement, the clerk of the court of common pleas of the county in which the last certificate of title to said motor vehicle was issucd, upon the surrender of the prior certificate of title or the manufacturer's or importer's certificate, or, when that is not possible, upon presentation of satisfactory proof to the clerk of ownership and right of possession to such motor vehicle, and upon payment of the fee prescribed in section 4505.09 of the Revised Code, and presentation of an application for certificate of title, may issue to the applicant a certificate of title to such motor vehicle. Only an affidavit by the person or agent of the person to whom possession of such motor vehicle has passed, setting forth the facts entitling him to such possession and ownership, together with a copy of the journal entry, court order, or instrument upon which such claim of possession and ownership is founded, is satisfactory proof of ownership and right of possession. If the applicant cannot produce such proof of ownership, he may apply directly to the registrar of motor vehicles and submit such evidence as such applicant has, and the registrar may thereupon, if he finds the evidence sufficient, authorize the clerk to issue a certificate of title...." (Emphasis added.)

28. Since the section authorizes clerks to issue certificates of title upon a court order that a motor vehicle has been transferred by law, the court must be able to hold that title has been transferred even though the certificate of title has not been transferred. 
parties, it may be considered as transferring ownership by operation of law or as an agreement analogous to those specifically mentioned in this section.9

If motor vehicle registration statutes warrant modification of the resulting trust doctrine, a more reasonable solution would be to abolish only the presumption that, where title was placed in someone other than the payor, the parties to a transfer of property must have intended to create a trust rather than to execute a gift. ${ }^{30}$ This would eliminate the advantage which the presumption provides the purchaser, but would nevertheless allow him to prove the relationship actually intended by the parties. Thus interpreted, the statute would create a presumption of ownership in the legal titleholder which might be overcome by the extraordinary degree of proof required to establish a resulting trust. ${ }^{31}$ Such proof would include evidence of dominion over, use of, and enjoyment of the property as well as evidence of the circumstances of the underlying transaction and the payment of the purchase price.

The intention of the Ohio legislature in passing the motor vehicle registration statute was "to prevent the importation of stolen motor vehicles and

29. It has been held that a resulting trust is a relationship created by operation of law. Campanello v. Miercer, 124 Mont. 528, 227 P.2d 312 (1951); Young v. Greer, 250 Ala. 641, 35 So. 2d 619 (1948); Albert v. Albert, 148 Kan. 527, 83 P.2d 795 (1938).

The creation of a resulting trust may be considered as the recognition of an implicdin-fact agreement. The trust is based on the presumed intentions of the partics inierred from the circumstances of a transfer of property. If the presumption of intention is not rebutted, an agreement between the farties that the titleholder is to hold only for the benefit of the purchaser is established. See 3 Scorr, Trusts $\$ \$ 404,404.1,404.2$ (1939). Such an implied-in-fact agreement would be similar in the nature of its origin to an implied-in-fact contract which is also inferred from the circumstances of a transaction in order to enforce the intentions of the parties. See 1 Wilnisto: Contrncts $\$ 3$ (rev. ed. 1936).

30. Elimination of the presumption which the resulting trust doctrine establishs in favor of the purchaser would call into play the presumption of ownership in favor of the titleholder which many courts have said is provided by the mutor velicle registration statutes. Speck Cadillac-Olds. v. Goodman, $373 \mathrm{~Pa}$. 83, 95 A.2d 191 (1953); Wren v. Bankers Inv. Co., 207 Okla 339, 249 P.2d 712 (1952); Nash Jliani Motors v. Bandel, 47 So. 2d 701 (Fla. 1950); Burakowski v. Grustas, 134 Conn. 205, 56 A.2d 461 (1947); Junkin v. Anderson, 12 Wash. 2d 58, 120 P.2d 548 (1941). Apparently the theory is that the motor vehicle purchaser is bound by constructive notice of the registration statute's provision that ownership is in the titleholder. Therefore he may be presumed to have intended to execute a gift when he had the vehicle registered in another person's name.

31. The proof of a resulting trust must be by clear, cogent, convincing, and urcquivocal evidence. Hadley v. Kays, 121 Ind. App. 112, 9S N.E2d 237 (1951); Sines v. Shipes, 192 Md. 139, 63 A.2d 748 (1949) ; Carrillo v. O'Hara, 400 III. 518 , 81 N.E.2d 513 (1943).

A previous Ohio case, Douglas v. Hubbard, 91 Ohio App. 200, 107 N.E.2d 894 (1951), appeal dismissed, 157 Ohio St. 94, 104 N.E.2d 182 (1952), stated that the statute did not remove motor vehicles from the law of resulting trusts and recognized a resulting trust in a truck. Finding a sufficiently high degree of proof to rebut the presumption of cwnership furnished by the certificate of title, the appellate court held that the legal title as evidenced by a certificate of title could be in one person and beneficial interest in another. See 101 U. PA. L. REv. 425 (1952). Though the Dotglas case was urged in the appellant's brief, Brief for Appellants, pp. 2, 5, 8, In re Estate of Case, 161 Ohio St. 2S8, 118 N..E2d 836 (1954), the instant case apparently overrules it without any reference to it. 
thefts and frauds in the transfer of title to motor vehicles ...."32 Attainment of this purpose does not preclude courts from ascertaining the circumstances under which a certificate of title was registered in a given name. ${ }^{33}$ The recognition of a resulting trust in a transaction in which neither theft nor fratud is involved would not conflict with the letter or the spirit of the statute. And the doctrine of resulting trusts recognizes that such trusts are unenforceable against bona fide purchasers without notice. ${ }^{34}$ The court has unnecessarily overturned a well established legal doctrine.

32. 117 Онго H.J. 323 (1937). See cases cited note 18 supra. There is no indication of any legislative intent to abolish resulting trusts in motor vehicles. If this had been the legislative intent, it could have been specifically indicated as in those few statutes which prohibit the recognition of purchase money resulting trusts in land. 3 Scorr, Trusts \$440.2 (1939); Gilmer, Current Development in Resulting Trusts and Constructive Trusts in Kentucky, $42 \mathrm{Kr}$. L.J. 455 (1954). The doctrine of resulting trusts is of such long standing that no court should assume a legisiative intent to abolish it in the absence of an express provision to that effect.

33. Erie County Bank v. Fowl, 71 Ohio App. 220, 227, 49 N.E.2d 61, 65 (1942) (dictum). The certificate of title is issued by the clerk of the court of common plcas of the county in which the applicant resides or, in case of an out-of-state resident, of the county in which the transaction took place. OHio REv. CoDE $\$ \S 4505.06,4505.08$ (1953). It does not seem reasonable that courts should be absolutely precluded from examining the circurnstances surrounding the issuance of a certificate merely because a clerk has decided to issue one. If such an examination shows that the certificate holder is without a right to possession, courts should deny him relief.

34. Patterson v. McKeehen, 168 Okla. 252, 32 P.2d 875, (1934); Poppke v. Poppke, 57 S.D. 262, 231 N.W. 933 (1930) ; Ransome v. Watson's Adm'r, 145 Va. 669, 134 S.E 707 (1926). 